\title{
"I came to art school so I wouldn't have to write...": Creating New Contexts for Critical Writing in Post-Secondary Art and Design Education
}

Addressing the impact of poststructural and postmodern discourses on composition studies and teaching writing in the West, Lester Faigley refers to the philosophical divide between "innerdirected" and "outer-directed" theorists in the composition field (31). According to Faigley, innerdirected theorists are concerned with the "how of composing" and are known to be staunch adherents of the process-oriented approach to teaching writing. Outer-directed theorists are concerned with the social contexts informing students' experiences of learning to write. They favour asking "why writers make certain decisions" and therefore believe, as composition studies scholar Patricia Bizzell has herself said, that "thinking and language use can never occur free of a social context that conditions them" (Bizzell as quoted in Faigley 31). The pedagogue who aligns herself with outer-directed theories would see her role as one of helping students join what might be an unfamiliar discourse community (31).

In this paper, I focus on particular social contexts informing the work of teaching and learning critical writing at the Ontario College of Art \& Design in downtown Toronto, Ontario, Canada. I do this, not to exclude inner-directed concerns around the 'how of writing,' but partly to explore the interdependence of inner and outer-directed composition theories in how both students and teachers understand teaching writing in higher education generally and art and design education more specifically. As an entry point to this exploration I propose three ways in which critical writing is constructed-ideologically and institutionally-as an interference to other creative practices students are pursuing as part of their art and design education at OCAD. My observations of the form of assessment in art and design education known as critique provides the basis for my reflection on how the pedagogy of critique in the composition classroom might work to resist ideological and institutional frameworks that negatively impact students' 
experiences of learning to write at OCAD. As education researcher, Deborah Britzman observes, subjectivity and one's "conceptual ordering of experience" are an "effect of discourse[s]" that serve a normalizing function (36). To disrupt and rework the outcomes of normative practices, Britzman suggests employing "suspicious discourses." My elaboration of the pedagogy of critique with respect to its own construction of the 'how' and 'why' of writing, represents my proposal for a positively 'disruptive' and 'suspicious' discourse for teachers and students in art and design, postsecondary education. ${ }^{1}$

\section{Constructions of Critical Writing as an Interference to Art and Design Education}

In English Canada, there are currently four art and design post-secondary institutions offering baccalaureate degrees in various streams of art and design. ${ }^{2}$ All of these institutions have their own permutation of a liberal arts faculty whose goal, in part, is to develop student critical literacy skills. By 'critical literacy' I mean a student's ability to use a language that, as composition theorist Ira Shor asserts, not only "questions the social construction of the self" (2) but also questions the social construction of knowledge, practice, and forms of representation more generally. The liberal arts curricula in Canada's art and design post-secondary institutions is generally aimed at offering 'breadth' requirements with the broader goal of encouraging student wisdom rather than technical or utilitarian expertise in a very specific area (Axelrod 42). At the same time, these liberal arts curricula are devoted to facilitating student achievement in "practices of inquiry" (37) and critical thinking as these practices are expressed in student oral and written competencies. At the Ontario College of Art \& Design, the Faculty of Liberal Studies offers courses that require students to engage in critical writing with the hope that they will learn a critical language that helps them situate their work, for themselves and others, historically, politically, ideologically and socially.

Despite the goals of liberal arts education at OCAD, I have experienced a particular kind of resistance to learning critical literacy skills and learning critical writing among students there.

\footnotetext{
${ }^{1}$ The thesis of this article is partly informed by conversations I have had, in person, by email, or through a process known as 'inkshedding,' with the following thoughtful colleagues: Kathleen Vaughan (York University), Tania Smith (University of Calgary), Kate Eichhorn (Ryerson University), Jacqueline Turner (Emily Carr Institute of Art \& Design), and Russ Hunt (St. Thomas University). Many thanks also to the following OCAD art faculty members who let me into their critiques: Catherine Beaudette, Vid Ingelevics, and Natalka Husar.
} 
This resistance, while certainly not pervasive in the college, is nevertheless present and I propose more significant and urgent as the institution begins to fully implement its degree programs. ${ }^{3}$ I think I can best exemplify this resistance through an anecdote. Within my first month of working at OCAD, I had an experience with a student that gave me pause. I was helping a group of firstyear OCAD students in a Liberal Studies class work through the requirements of an essay assignment in a workshop format. One student put up his hand and expressed his frustration with the assignment (and maybe with me too). In a joking but exasperated tone he said: "I came to OCAD so I wouldn't have to write."

Admittedly, this is an extreme and complex statement that can be interpreted and explained in all kinds of ways. It is also the discursive signal of a momentary social relation infused and shaped by categories of difference—teacher/student, woman/man, academic/artist (I could go on). I bring this story up, not to frame this particular student or OCAD students in general, in a negative way. Rather, I seek to direct attention towards a perception of the pedagogical value of critical writing and critical literacy which is a current challenge at OCAD and possibly other art and design institutions in Canada.

How can I make sense of this student's somewhat confrontational comment that he came to OCAD so he "wouldn't have to write"? My inclination is to read the student's remark as the effect of ideological and institutional discourses about critical writing that are embedded in dichotomies, mobilized by students and faculty at OCAD as a defense against writing, and therefore ultimately an obstacle to liberal arts education in an art and design postsecondary context. The most pervasive and destructive discourse can be found in how students understand theory and practice as it relates to making art and design objects and making written work in a liberal arts classroom. This interfering discourse gives rise to another; that is, the perceived mutual exclusivity of visual and verbal literacies and learning preferences.

The following series of relationships ideologically embedded and therefore unwittingly reinforced at OCAD, work against student enthusiasm for liberal arts education in the context of

\footnotetext{
${ }^{2}$ The institutions being referred to here are, from western to eastern Canada, Emily Carr Institute of Art \& Design, Alberta College of Art \& Design, Ontario College of Art \& Design, and Nova Scotia School of Art \& Design.

${ }^{3}$ In 2002 the Ontario College of Art \& Design gained accreditation as a baccalaureate degree-granting institution. Students wishing to complete either a BFA (Bachelor of Fine Arts) or BDes (Bachelor of Design) at OCAD now have to complete the equivalent of 10 half-courses in Liberal Studies rather than eight, as was the case before university
} 
art and design education. Put somewhat crudely here, the series of relationships adheres to this logic: Liberal arts courses are for studying art and design theory whereas art and design courses are for making art and design objects. Critical writing, as symbolic practice, serves art and design theory and is unrelated to art and design practice. Art and design theory and art and design practice are also unrelated to each other.

When one assumes that art and design theory and practice have nothing to say to each other, a number of conceptions of practice relative to theory are put into play. One such conception rests on a notion of art as non-ideological. In this view, art objects are constructed as "closed, self-contained, and transcendent entities" (Wolff 49). Art has autonomy and resides in a category separate from culture, the social, and discourse. In turn, the history of art is seen as an "intrinsic development of style, independent of social or historical factors outside the aesthetic sphere." For many of us, schooled in post-structural and post-modern discourses in the humanities, art, or education, the idea of art as non-ideological seems far behind us. However, literary scholar, Wendy Steiner, points to the persistent, North American, cultural attachment to the purpose of art as purely aesthetic; a notion that upholds claims that art is and should be 'familiar,' 'harmonious,' and 'beautiful' (Steiner 3).

Another conception mobilized by an ideological division between art and design practice and theory is the idea that critical theory is a 'dead-end'-impenetrable as a mode of understanding and without 'real world' applications. My student's comment can be read for a theory of theory as distinct from, abstracted, and moreover separated from practice and therefore not valuable pedagogically in an art and design university. Shor refers to a genre of theoretical discourse like this in higher education, calling it "theorizing theory" or "words without worlds" (11). My student can be understood as interpreting liberal arts curricula, and critical literacy more specifically, as instruction in 'words without worlds'; a course of learning without implications for practice and therefore bereft of true meaning and value in the world. The irony here is that critical literacy education is about "words rethinking worlds" (1) and by extension also about encouraging students to think and act differently—socially and politically. Critical literacy education assumes that all practice, including visual practices of creating art and design objects, are embedded in

accreditation. In addition, students entering OCAD from high school are now required to complete the equivalent of a full year course in visual culture and a half-year course in critical writing/composition. 
and express culturally specific systems of meaning. In other words, practice is always rehearsing some choreography of cultural meaning.

Another binary, both ideologically manifest and institutionally made at OCAD, is that between visual and verbal literacies. Specifically, I can read my student's comment as a claim for the 'naturalization' of certain competencies—visual and verbal competencies being the most germane. What gets mapped onto this effort to naturalize is a concomitant claim that verbal competency precludes visual competency and vice versa. The theory of competencies as naturalized, and to some extent mutually exclusive, is supported by popular understandings of the research of psychology and education scholar, Howard Gardner. His book about multiple intelligences, published in 1983 and entitled Frames of Mind, has profound currency in North American education circles even today. Although Gardner does emphasize in a 1993 introduction to Frames of Mind that socio-cultural contexts play a role in the development of the intelligences, nevertheless the intelligences "can be understood at the neurological or the biochemical level" (39). More specifically, Gardner claims that both visual-spatial intelligence (exhibited in artists) and linguistic intelligence (found in poets and writers) are located in different parts of the brain (98).

Apart from Gardner's actual intentions in writing Frames of Mind, popular culture has taken Gardner's research to mean that people are predisposed and therefore biologically predetermined to be fluent in certain forms of literacy and thinking to the exclusion of others. What I aim to highlight is how this cultural notion of naturalized and independent multiple intelligences is mobilized as a defense and/or resistance against critical theory and writing pedagogy at OCAD. My student's claim that he came to OCAD so he "wouldn't have to write" is understood then as an assertion of his natural capacity in the visual-spatial sphere and not the linguistic one. To some extent, this viewpoint represents an interference to this student's development as a critical writer and thinker in liberal arts and art and design courses.

Hidden in the assumption that visual-spatial and linguistic competencies are mutually exclusive is a related assumption that the expression of these different competencies is also entirely different. To some extent art and design undergraduates, who arrive in liberal arts classrooms quite comfortable with visual media as tangible material for composition and expression, often do not perceive language with respect to composition in the same way. In other 
words, to some art and design students, language is an oddly immaterial medium. Critical and other forms of academic writing are grounds for proving a thesis rather than a means for using the structure, form, and sound of academic English and composition to express sentiment, affect, or ideas. These beliefs are absolutely detrimental to student critical literacy learning in an art and design postsecondary context. Looking at my student's comment from this perspective draws into focus my student's frustration with learning a medium he perceives as completely foreign to visual media in art and design.

The ideological division between art and design theory and practice and visual and verbal literacy is also enacted institutionally through the separation of liberal arts instruction from art and design instruction at OCAD. While not a complete separation, liberal arts and art and design education are distinguished administratively (art, design, and liberal arts are housed in separate faculty and administrative offices) and in terms of curriculum and credits (liberal arts credits are distinct from design and art credits). The division is also enacted with respect to the physical and qualitative difference between conventional classroom teaching (liberal arts) and studio-based teaching (art and design) at OCAD. The implications of these divisions, in the context of other ideological and institutional constructions of critical literacy and writing pedagogy explored here, is that liberal arts at OCAD is understood as the 'academic' or 'theory and writing' side of the curriculum whereas the studio supports the 'real' and 'practical' work of educating artists and designers.

\section{A Short Story of Formative Critique in a Drawing and Painting Studio}

In 2004 I began undertaking institutionally-based research on the practice of critique at the Ontario College of Art \& Design. Critique is a common form of assessment used in studio classrooms in both art and design and therefore an essential component of the art and design curriculum at OCAD. As curriculum, critique is an enacted discourse; in the studio, it functions as a specialized and symbolic practice that constructs its subjects (the fields of art and design, individual student works, student and teacher identities, learning) in specific ways. I became interested in learning more about qualities of critique; specifically, how certain qualities of critique as discourse can be employed in the teaching of writing to inspire art and design students to develop themselves as critical writers. 
Critique is used as a form of summative and formative assessment. In most critiques, students show their art and design work to instructors and peers in the classroom for the purpose of receiving feedback and evaluation. Critiques are typically judicative, descriptive, or a combination of both (Elkins 152). Through observing five studio critiques in the Faculty of Art in the spring of 2004, I developed a set of questions for myself: What 'best' qualities of critique as symbolic practice could be brought to the composition classroom to disrupt the ideological and institutional divisiveness between the liberal arts learning environment and the art and design learning environment? How would these 'best' aspects of critique shift how students understand learning to write critically?

As a member of the liberal arts faculty at OCAD and therefore an educator more familiar with OCAD's conventional university classrooms, certain qualities of the studio and studio critique stood out for me as I observed both faculty and students interact with each other and the student work hung on the studio walls. The following short narrative is a pastiche of actual conversations, observations, and interactions I recorded as witness to five critiques in the Drawing and Painting, final year class. The pastiche has been put into narrative form. Most moments in this narrative have been fictionalized to create a sense of story. I also made an effort to paint a picture of critique in the studio, through enhanced description of sensory details, to emphasize the qualitative aspects of studio as a ground for teaching and learning.

The following narrative is also a representation of a 'good' critique, from my perspective as a university-level educator but not a studio teacher. My efforts to paint a picture of critique that evokes the 'good' in studio-based art and design education bears some resemblance to 'portraiture' as a methodology in the human sciences. In The Art and Science of Portraiture, Sara Lawrence-Lightfoot reflects on the evolution of portraiture as her unique methodology in investigating American high schools. Of her descriptive portraits of high schools, ethnographic in spirit, Lawrence-Lightfoot says: "I wanted to develop a document, a text that came as close as possible to painting with words" (4). Portraiture felt appropriate to my project partly because as a research methodology it mimics the sensibilities and methodologies of artists in the studio. More importantly, portraiture as methodology acknowledges that the 'real story' of critique cannot be accessed. All of those involved in human research (the researcher, the participants, and the artifacts of research) are, as Britzman points out, "textualized identities" (28). These identities are 
not authentic and not true but rather invested in discourses that "promise [the] pleasure" (27) of authenticity and truth in ethnography and human research.

Of her desire to represent what is 'good' in portraits, Lawrence-Lightfoot points out that portraiture as methodology is "an intentionally generous and eclectic process that begins by searching for what is good and healthy and assumes that the expression of goodness will always be laced with imperfections" (9). My portrait has not addressed the complexity of critique; a complexity that is, in fact, at its core. ${ }^{4}$ Bracketing off the complexity of critique serves my purposes for now, as adequate attention to this dimension of critique is beyond the scope of this stage of my inquiry.

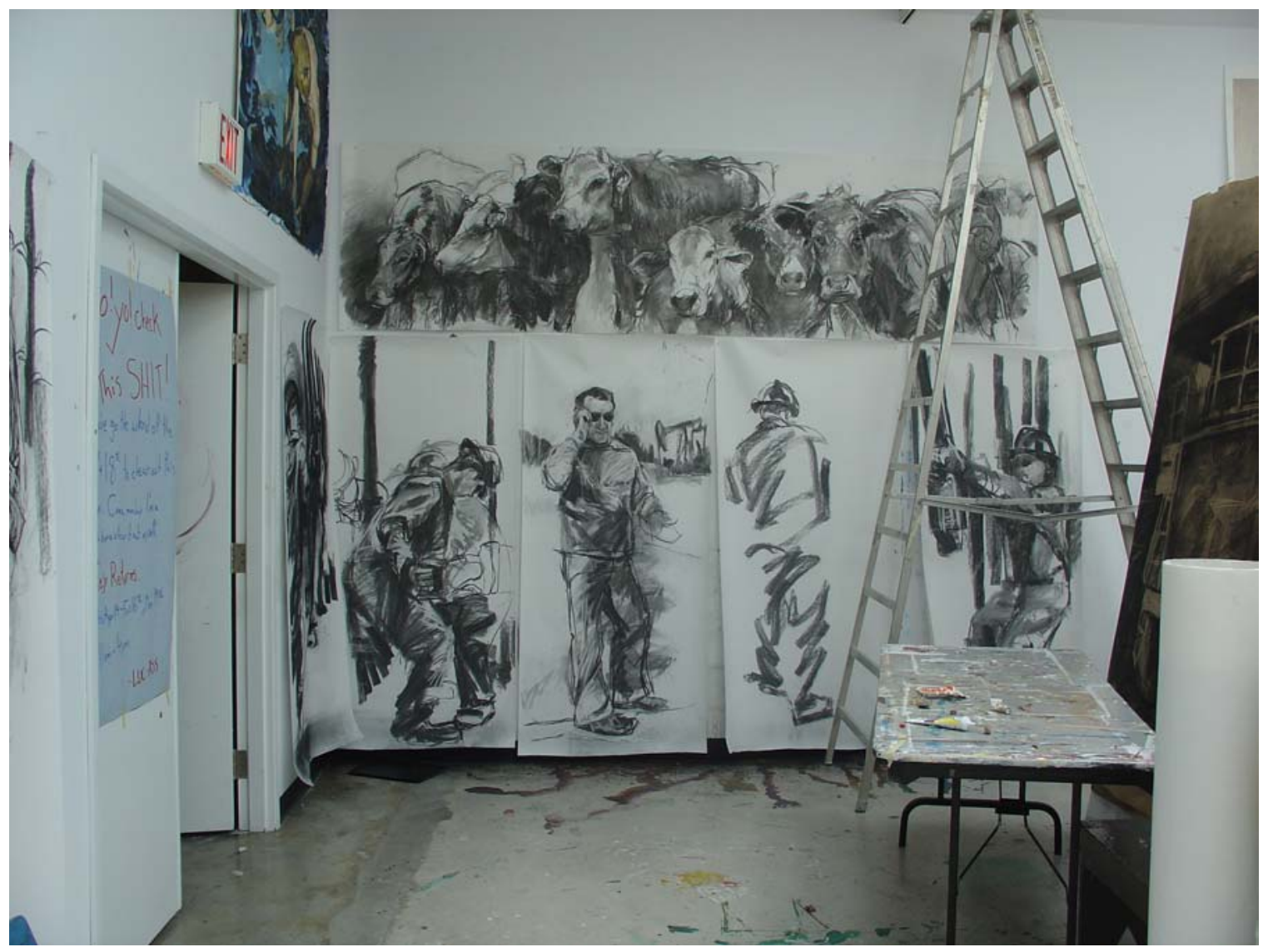

We are all bathed in the bright, new, white light of early spring filtering through the skylight. There is a sense of free, unstructured space in this studio-a refreshing airiness that is so welcome to me after a morning spent sitting in my cramped 'officey' looking office. I see some students

\footnotetext{
${ }^{4}$ Elkins refers to this complexity in a chapter of Why Art Cannot Be Taught entitled "Critiques." He states that critiques are "unbelievably difficult to understand and rich with possibilities. All kinds of meanings, all forms of understandings, can be at issue. Critiques can be like real-life situations: they can mimic seductions, trials, poems, and wars. They can hold nearly the full range of human responses-and that is only appropriate, because artworks themselves express the widest
} 
conversing on an old, spotted couch at the back of the studio. Another pair of students help each other put away brushes, paints, and a cumbersome canvas to be taken home later. One student is working. He has a large piece of white paper stapled to his studio area and, with a thick brush; he paints strokes of electric blue across the paper in no obvious pattern. Meanwhile, an even beat pulses from the earphones plugged into his ear; "boom, ba, boom, ba" is the white noise of the studio at the moment. Another student sits nearby, reading and munching an apple.

Critique hasn't begun yet and so the students are unsettled. They are coming in and out of the studio, laughing, chattering, carrying coffees and checking for messages on their cell phones. One student walks in with the instructor and the other two women who will be leading critique today. I approach the instructor to remind her of my presence, but there are students, backpacks, and the wood partitions used as a surface for painting, in my way. I take a detour through the studio to get closer to the instructor. Everywhere I see the artifacts of creation: tossed-aside and paint-soaked paper, cloth, and pens; splatters of every colour on the walls and furniture; shoes and jackets dropped on the floor; messages to each other on most blank surfaces ("Bobby Wong was here," "Went to the cafeteria for coffee. Meet you there at 6."). I feel disorganization and mess in this space, but comfort too, surrounded as I am by the working materials for creating things.

I hear the Instructor say: "O.k. Why don't you begin? Tell us about this painting. What are you trying to get at here?" The instructor points to a very large self-portrait on canvas that is stapled to the studio wall behind the student.

spectrum of human response. But the price critiques pay for that richness is very high. Critiques are perilously close to total nonsense" (166). 


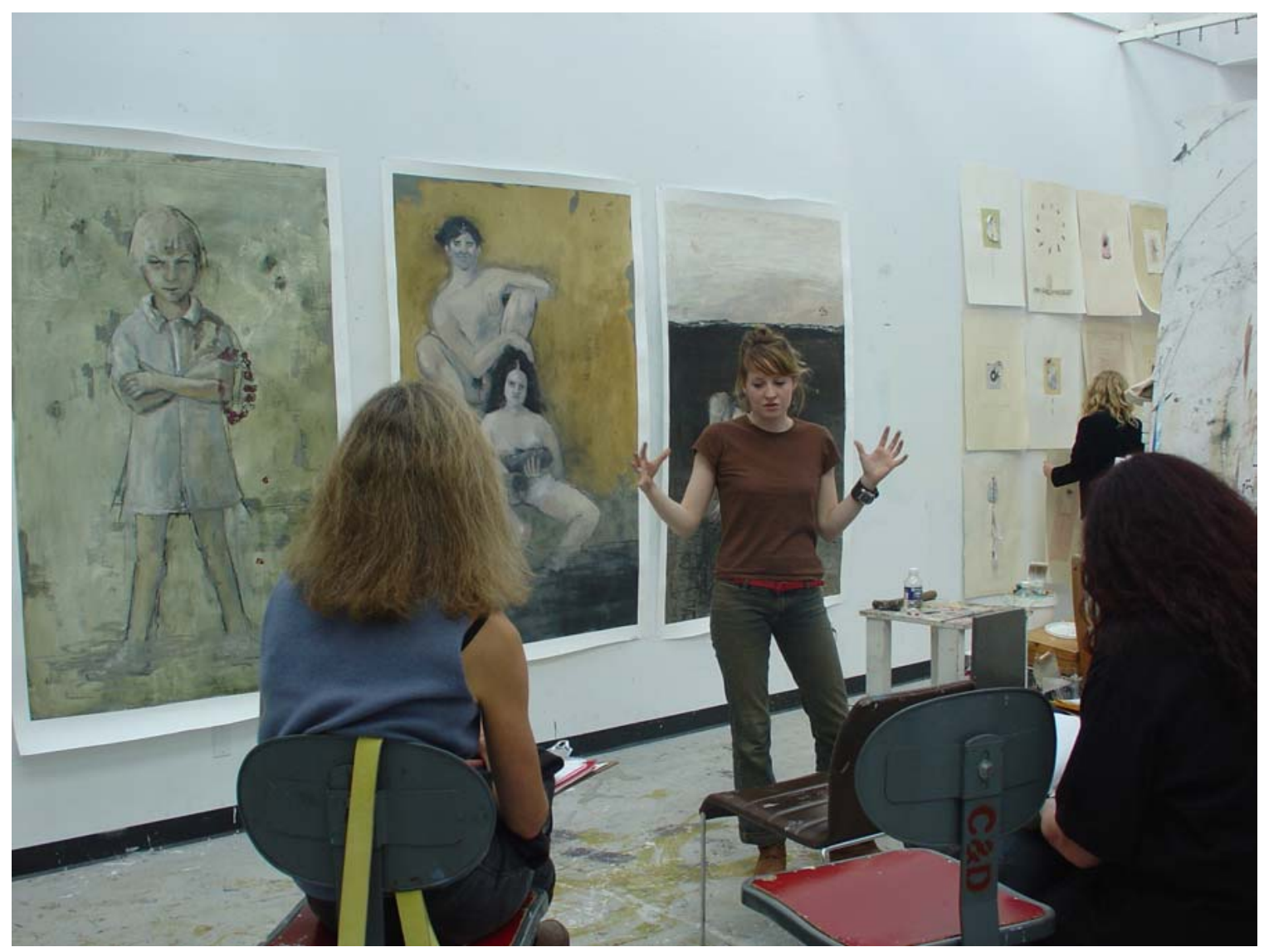

The student begins to describe his intentions in creating the self-portrait. He addresses the other four students in his critique that have gathered round, and the three instructors who are placed prominently in the circle of observers. The group studies the student's work intently, moving closer to observe paint and brush strokes and then moving farther away to take in the whole image. There are lapses in the student's speech about his own work. All three instructors allow these lapses and silences to pass, making space for the student to fill in gaps in discourse with his own knowledge about how he made the painting and what it means to him.

The instructors, each in their turn, begin modeling responses to the self-portrait. At first, responses take the form of queries. One instructor asks the student to articulate for everyone the themes of his painting and how these themes relate to other paintings the student has created for the course. Another instructor asks about the student's process in creating the work: What materials were used? How did the student make decisions about the relationships between elements in the painting? The student tries answers to these questions, and then the third 
instructor encourages other students in the group to step in and either respond to the painting or ask something of the painter.

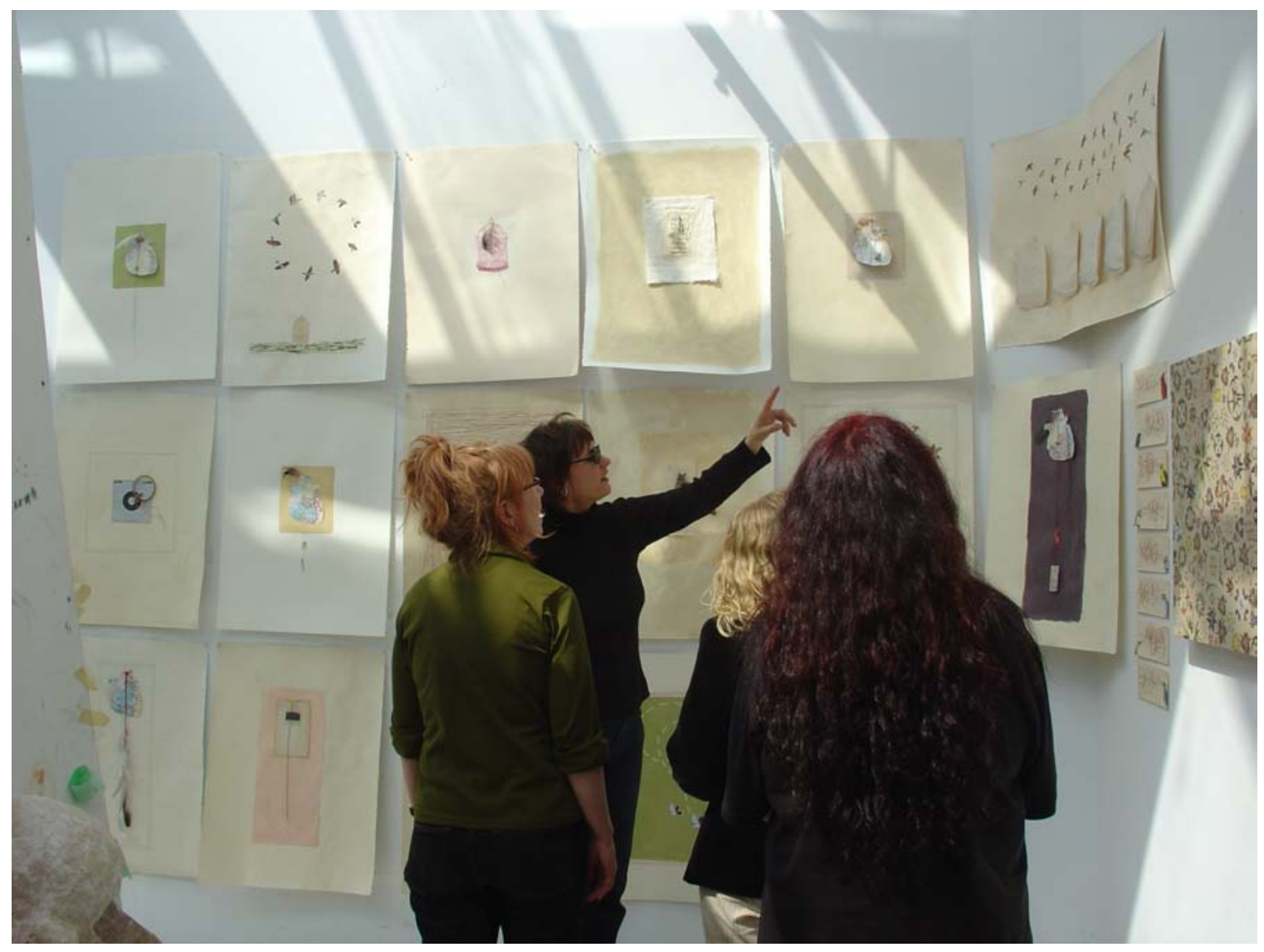

The other students demonstrate surprising comfort in giving feedback to the young painter and his portrait. It's clear that the students are used to giving each other constructive and interpretive feedback. One student comments that the painting is reminding her of the work of contemporary American artist, John Currin. She goes on to describe elements of the painting that remind her of Currin. One of the instructors jumps in with the comment that, yes, this painting is reminiscent of Currin and also clearly related to the student's other work as it has been evolving in the course. The other students voice agreement to this observation, and extend it with their own observations. A conversation erupts about the merits and impact of Currin's work and the ways in which the student's work is both similar to and a departure from Currin.

At one point in the discussion the student begins talking about some challenges to his process of creating the painting and how these challenges are reflected in certain unsuccessful elements in the work. One of the instructors begins to reflect on the student's difficulties. She points out 
ways in which the student could have avoided these difficulties and she suggests that certain difficulties identified by the student can be interpreted as not difficulties at all. This response occurs as the instructors and students observe the surface of the painting. The students offer their own helpful suggestions to the student being critiqued-couching these suggestions in their own experience with certain media and materials. The students' suggestions build on each other, and by the end of the critique the student in question has a wealth of feedback to apply to future work and the re-working of the painting on the wall.

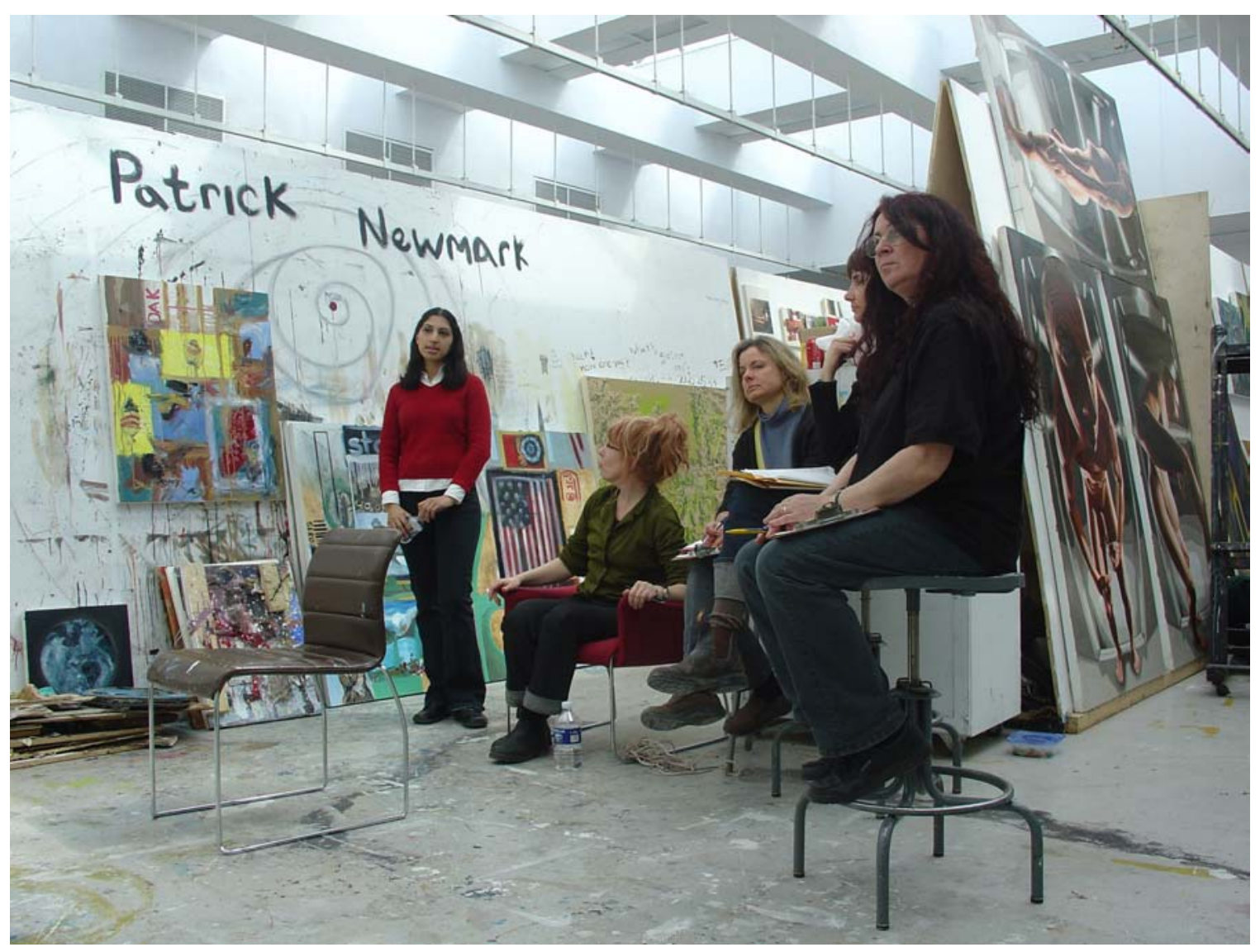

Each of the instructors comments on aspects of the painting that are particularly strong and compelling, also making suggestions for how to develop these elements in future paintings. Again the instructors open it up to the other students, asking them to offer their own opinions about what they like in the painting: What images, colours, approaches, and media should be carried over and developed in other work? What is not working in the painting and perhaps should be reconsidered in future work? As the students offer their responses to these questions, the young painter reflects on them out loud. In the conversation that ensues, the student begins 
to speak with more strength and confidence about his unique style, process, thematic preoccupations, and choices in making paintings.

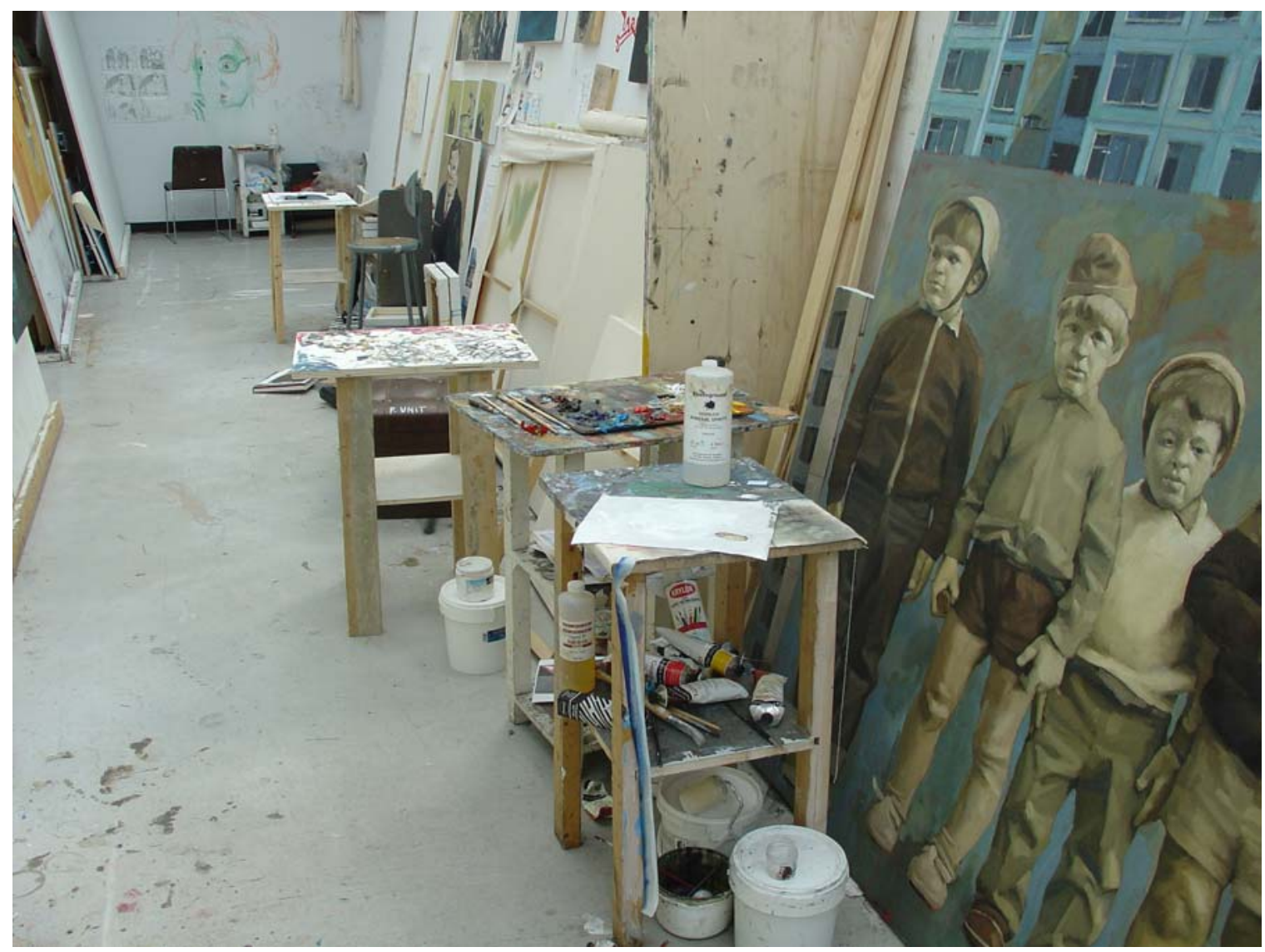

\section{The Pedagogy of Critique as a 'Suspicious Discourse' in Critical Writing Courses}

There are three qualities of studio critique that I find interesting to think about in terms of their potential to disrupt and transform how art and design students understand critical writing and in turn the work of learning to write critically. These qualities are studio critique's focus on objects of student creation as aesthetic objects, the way in which critique allows students to test their own difference from and attachment to their objects of creation, and the opportunity studio critique gives students to narrate their own and other students' stories of composition and creation. All of these aspects of critique can be understood as classroom discourses with significant potential for resisting student resistance to critical literacy instruction and critical writing in the liberal arts classroom. All of these discourses of critique have the potential to subvert divisive and destructive distinctions that art and design students are susceptible to making between theory 
and practice, liberal arts and art and design, visual-spatial thinking and verbal thinking, and visual literacy and verbal literacy.

In what follows, I move through an examination of three discourses of critique and comment on their power to transform the liberal arts writing classroom in a postsecondary art and design classroom. My observations of studio critiques at OCAD tell me that there is something potent for both students and instructors in the process of showing visual work as part of a process of learning in an art curriculum. Of the power of painting, phenomenologist Maurice MerleauPonty claims that "painting celebrates no other enigma but that of visibility" (127). Qualifying this point in his typically opaque style, Merleau-Ponty suggests that "The painter's gaze asks [visual objects] what they do to suddenly cause something to be and to be this thing, what they do to compose this talisman of world, to make us see the visible" (128). In a studio critique, all participants—students, guests, instructors—are adopting the painter's gaze to discern and interpret what is made visible in paintings. Students put visual work on the wall so it can be seen, pondered, observed, questioned, and responded to. Indeed, the exhibition of student work is crucial to studio pedagogy. In critique, revelation is essential; that is, revelation of intent, process, and interpretation of success. Students are asked to stand beside their work, speak to their work, and contextualize their work for peers and others. They are continually laid bare and made vulnerable in front of an audience and this is usual-part of the scene and scenery of critique. Most importantly, students and instructors approach visual work in critique, not just to evaluate the content, but also the formal properties of the work or how the work was made.

In this context, the materiality of visual media and the overall 'discursivity' and visibility of drawing and painting is celebrated. For students this centres questions about modes of representation, choices in representation, and the resultant impact of these modes and choices for meaning and reading. Therefore, the most pedagogically significant change that critique as symbolic practice could bring to the teaching writing scenario would be to (1) situate language as material for the expression of ideas (equivalent to colour, texture, and line) and (2) designate student writing as an object for aesthetic concern like any public artifact.

This does not mean that teachers in liberal arts classrooms at art and design universities should immediately start taping essays to classroom walls and forcing all students in a class to participate in reading each other's work in this way. But I do think that, as a general rule, writing 
is an entirely too private activity in liberal arts classrooms. This is especially true in critical writing classes where students are asked to think and write with the ideas of 'knowledgeable authorities' through individual research in libraries and private composition at home or in the computer lab. Making student attempts to create critical writing more public means subtly shifting orientations to academic writing from utilitarian ones (about proving the all too powerful thesis) to aesthetic ones. What if liberal arts students shared their work in writing seminars mandated by the curriculum to support development of an extended piece of writing like an honours essay? What if a liberal arts student was continually required to speak to her peers and instructors about her rationale for adopting a specific methodology, or structuring her research paper in a certain way? What if a liberal arts student, over the course of a year, regularly had to bear witness to other student's reactions to his writing for a liberal arts class, and similarly had to engage with colleagues and instructors about the merits and deficiencies of the work? I suggest that the ensuing conversations would attempt to identify what education researcher Elliot Eisner calls the elements of artistry; that is, craft, rhetoric, sensibility, imagination, technique, and the "significance of the particular" (382) in the writing. In this scenario, the process and goals of composition in art, design, and liberal arts are not entirely dissimilar.

Elkins observes that: "Most critiques maintain the strange fiction that the work can be considered entirely apart from the person who made it. There are exceptions: in performance art, for example, the emotional content of the work cannot always be distinguished from the emotional state of the artist... Since most critiques are somewhere between [these] two extremes, it is usually possible to proceed as if the critique is not personal, though I would say that it is not a bad idea to keep in mind just how artificial that enabling fiction really is" (132). In response to Elkins' observation, and given my own observations of critique, I would say that critique is the stage where student artists test out a distancing and concomitant personal attachment to their own creations. What enables this performance, in part, is the act of making work public-visible-and thus an object for aesthetic attention and interpretation. The way in which critique enables the 'trying on' of otherness and attachment in front of a public comprised of peers and teachers is a second potential for studio pedagogy in a teaching writing classroom.

Critiques encourage the artist to try being an 'other' to her own work-another reader in dialogue with peers and authorities in the field as they stand before the painting and adopt the 
painter's gaze. The complement to testing out otherness is testing attachment to one's own creation in a public domain. As Elkins points out, the 'non-personalness' of critique is an enabling but ultimately artificial fiction. It is clear to me, in observing critique, that critique cannot avoid becoming a learning context where students test their attachment to their visual work. Physically standing beside a painting and saying 'this is my painting,' 'I made it,' and 'this is what I wanted it to mean' is a subtle but powerful pedagogy for students in art, design, and I suggest the liberal arts. Through critique and being present to critique discussion, students in liberal arts courses can ask: Do I want this work to be connected to me? And, is this how I want to express myself? These points of inquiry are ultimately about the creator and/or author asking: What kind of painter and/or writer do I want to be?

If a writing class in liberal arts put a priority on helping students 'test out' being other to and the same as their written productions, the class might spend a lot of time engaged in an expanded peer review process. This would not take the form of one-on-one peer review but peer review of one with seven or eight, including an instructor who coached students through a studio critique of the student writing. The peer review group would necessarily need to be coached in asking critique-like, open-ended questions about intended meaning, personal composition strategies, and process. The peer leader or instructor would also have to reveal himself as a practitioner to the students, sharing his or her own composition strategies, process, perceived composition failures and successes. Again, there are possibilities here for resisting ideological and institutional contexts that entrench divisions between liberal arts, critical writing instruction and art and design education.

Finally, I am interested in the potential of critique as a context for students narrating their evolution as creators of art and design objects, makers of cultural meaning, and technicians. Of the role of narrative in critique, Elkins writes that "Critiques can also be seen as exchanges of stories, or collaborative storytelling... Critiques are the intersection, or battleground, of different stories about art" (144). My observations of OCAD critiques bear out Elkins's statement. Indeed, stories were spontaneously made by students, instructors, and guests alike in all of the critiques I witnessed. But there was one kind of story that interested me the most for its pedagogical potential; that is, the story of the artist and her evolution as artist in the context of the studio class. A number of times I saw students and instructors react to student work being critiqued with 
statements like the following: "I like how you changed this—it's a nice departure from what you were doing last month" or "I'm glad that you kept this in your painting—-this form is unique to you and reminds me of how you have been working all along."

Conversations would ensue where students and instructors elaborated the history of the work of the student being critiqued as the context for the work being considered. I suggest that the benefit for the student being critiqued is an insight into how others view her learning and development as a practicing artist. In a liberal arts writing classroom it is typically the instructor who offers this kind of insight and mentorship. But in critique, again, the 'publicness' of the process enables the sharing of the teaching role. Peers and instructors can build on each other's discourse about where the student has been creatively and where she is going, to produce a story about growth and development that is complex, open-ended, and most importantly multivocal.

The weaving of multi-vocal stories about the creator's evolution and development is my final proposal for the possibility of studio critique for teaching writing in liberal arts. Students and instructors become intimate with each other's stories of development because studio critiques occur throughout the year and also because studio promotes the showing and revelation of the products of creation. I suggest that this needs to happen more in writing classrooms because narrating development encourages students to understand creation as a process that is nonlinear, perhaps circuitous, caught within a web of other concerns (personal, professional), and subject to failure, starting over, and success. Moreover, this aspect of critique in the critical writing classroom demonstrates to art and design students that visual and verbal rhetoric and composition strategies resonate with each other rather than strictly oppose each other. Engaging art and design students in a process of narrating and reflecting on their development and process in creating works of writing might serve to upset perceived distinctions between art, design, and liberal arts education in art and design universities.

In a recent keynote address, award-winning teacher and professor of cognitive science, Claude Lamontagne, commented that the best teachers are not didactic in their approach to educating students in a specific discipline (STLHE Opening Plenary Keynote, May 2004). Rather, good teachers know to keep their students close to the messy and complex genesis of creating discipline-specific knowledge. They keep their students 'close' by making explicit the genesis of 
their own expertise and using their insight to encourage students to move through their own personal processes of meaning making. The qualities of critique as symbolic practice in the art and design studio that I have explored here support a partial reversal in the way composition is often taught at the post-secondary level. I propose that critical writing pedagogy which emphasizes the materiality of language, provides an aesthetic orientation to the products and processes of written composition, creates awareness of the parallels between verbal and visual rhetoric and languages, and embraces development, is anti-didactic pedagogy that values student involvement in the 'genesis' stage of knowledge and knowledge-production. Art and design universities in Canada educate 'makers' of culture and a pedagogy that encourages the learning of 'makers' of culture broadly conceived to include critical writing would promote student confidence in moving between liberal arts, art, and design curriculum requirements. 


\section{WORKS CITED}

Axelrod, Paul. Values in Conflict: The University, the Marketplace, and the Trials of Liberal Education. Montreal: McGill-Queen's University Press, 2002.

Britzman, Deborah. "'The Question of Belief': Writing Poststructural Ethnography." Chapter in Working the Ruins: Feminist Poststructural Theory and Methods. Eds. Elizabeth A. St. Pierre and Wanda S. Pillow. New York: Routledge, 2000.

Eisner, Eliot W. "From Episteme to Phronesis to Artistry in the Study and Improvement of Teaching." Teaching and Teacher Education 18 (2002): 375-385.

Elkins, James. Why Art Cannot Be Taught. Chicago: University of Illinois Press, 2001.

Faigley, Lester. Fragments of Rationality: Postmodernity and the Subject of Composition. Pittsburgh: University of Pittsburgh Press, 1992.

Gardner, Howard. Frames of Mind: The Theory of Multiple Intelligences. $10^{\text {th }}$ ed. New York: BasicBooks, 1983.

Lamontagne, Claude. "Of Course They Can Learn, But Do We Really Teach?" Opening Plenary Keynote. Conference of the Society for Teaching and Learning in Higher Education. University of Ottawa, Ottawa ON. June 17-19, 2004.

Lawrence-Lightfoot, Sara and Jessica Hoffman Davis. The Art and Science of Portraiture. San Francisco: Jossey-Bass, 1997.

Merleau-Ponty, Maurice. "Eye and Mind." Chapter in The Merleau-Ponty Aesthetics Reader: Philosophy and Painting. Evanston IL: Northwestern University Press, 1993.

Shor, Ira. "What is Critical Literacy?" Journal for Pedagogy, Pluralism \& Practice 1(1999) 4 Mar. $2003<$ www.lesley.edu/journals/jppp/4/shor.html>

Steiner, Wendy. The Scandal of Pleasure. Chicago: University of Chicago Press, 1995.

Wolff, Janet. The Social Production of Art. New York: New York University Press, 1981. 